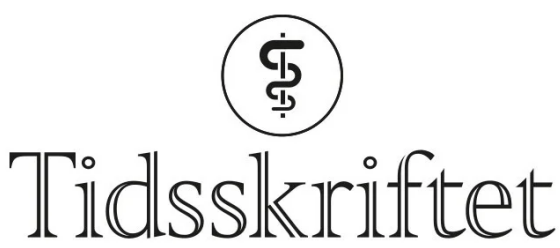

DEN NORSKE LEGEFORENING

\title{
Correction: Ketamine for depression - evidence and proposals for practice
}

RETTELSE

TOR-MORTEN KVAM

LOWAN H. STEWART

ANDREAS WAHL BLOMKVIST

OLE A. ANDREASSEN

Tidsskr Nor Legeforen 2021; 141. doi: 10.4045/tidsskr.21.048o.

In the English version of the article the following should be written: Although knowledge about adverse effects and the duration of the effect is somewhat deficient, we believe that the time has come to start clinical treatment in Norway.

We apologise for the error, which has been corrected online.

Publisert: 10. november 2021. Tidsskr Nor Legeforen. DOI: 10.4045/tidsskr.21.076o

(C) Tidsskrift for Den norske legeforening 2023. Lastet ned fra tidsskriftet.no 26. april 2023. 